\title{
Influence of bovine ampullary and isthmic oviductal fluid on sperm-egg binding and fertilization in vitro
}

\author{
A. L. Way, A. M. Schuler and G. J. Killian* \\ Dairy Breeding Research Center, The Pennsylvania State University, University Park, PA 16802, USA
}

\begin{abstract}
The objective of this study was to determine the effects of oviductal fluid on sperm binding and fertilization in vitro when either bovine oocytes or both spermatozoa and oocytes are incubated in fluid from different regions of the oviduct and at different stages of the oestrous cycle. Oocytes, or oocytes and spermatozoa, were incubated in nonluteal and luteal oviductal fluid obtained from the whole, isthmic or ampullary oviduct of dairy cows. Gametes were washed and coincubated in fertilization medium for $18 \mathrm{~h}$, and then observed for sperm binding and penetration. More spermatozoa bound to oocytes that were preincubated in nonluteal oviductal fluid than to those that were incubated in luteal oviductal fluid; however, there were no differences in fertilization rates between the two treatments. More spermatozoa bound to oocytes incubated in isthmic than in ampullary oviductal fluid. However, if both gametes were incubated in oviductal fluid before their coincubation, binding was higher when both gametes were incubated in ampullary oviductal fluid. By reducing the time of coincubation of spermatozoa with the oocytes, differences in fertilization rates were seen among the various oviductal fluid treatments. At 14 and $16 \mathrm{~h}$ of coincubation, more oocytes were fertilized if spermatozoa were preincubated in isthmic oviductal fluid and oocytes were preincubated in ampullary oviductal fluid than if both gametes were incubated in whole or ampullary oviductal fluid. Because both sperm binding to the zona pellucida and fertilization rates were greater in treatments in which gametes were exposed to regional oviductal fluid than when they were incubated in whole oviductal fluid, it is concluded that oviductal fluid from different regions of the bovine oviduct may play different roles in facilitating fertilization.
\end{abstract}

\section{Introduction}

Oviductal fluid, a secretion and transudate of the oviductal epithelium, is a dynamic fluid thought to influence sperm capacitation and the acrosome reaction, fertilization and early embryonic development. Several studies have described differences in the composition of in vivo derived bovine oviductal fluid, depending upon stage of the oestrous cycle and region of the oviduct (Carlson et al., 1970; Roberts et al., 1975; Killian et al., 1989; Ehrenwald et al., 1990; Gerena and Killian, 1990; Wegner and Killian, 1992; Grippo et al., 1992). Other reports have described the effects of oviductal fluid on bovine spermatozoa (Parrish et al., 1989; Ehrenwald et al., 1990; McNutt et al., 1992; McNutt et al., 1994); however, these studies involved the use of whole oviductal fluid, which is not derived from a specific region of the oviduct.

Differences in the secretion of certain glycoproteins associated with region of the oviduct have been noted by the use of in vitro explant and epithelial cell culture (Hyde and Black, 1986; Verhage and Fazleabas, 1988; Buhi et al., 1989; Buhi et al., 1990). An oestrus-associated glycoprotein has been shown to

*Correspondence.

Received 7 June 1996 influence sperm capacitation (King et al., 1994), the acrosome reaction (Boatman et al., 1994; Boatman and Magnoni, 1995), motility and viability (Abe et al., 1995) and fertilization (King et al., 1994; Boatman et al., 1994; Kimura et al., 1994) in a variety of species. This glycoprotein is bound by bovine spermatozoa (King and Killian, 1994; Abe et al., 1995) and is prevalent in the ampullary region of the oviduct (Wegner and Killian, 1992).

Staros and Killian (1995) found that five oviductal fluid proteins consistently associated with bovine zonae pellucidae incubated in both luteal and nonluteal oviductal fluid. In addition a sixth protein, identified as the $95 \mathrm{kDa}$ oestrusassociated protein, associated with zonae incubated in nonluteal oviductal fluid. Oviductal fluid proteins also associate with the bovine sperm plasma membrane (McNutt et al., 1992; Rodríguez and Killian, 1995). These proteins, adsorbed to either the zona pellucida or the sperm plasma membrane may facilitate sperm binding and fertilization.

Anderson and Killian (1994) described the effects of medium conditioned by ampullary and isthmic oviductal explants on sperm motion and capacitation, and determined that conditioned medium from isthmic oviductal explants enhanced sperm capacitation. In addition, Grippo et al. (1995) have shown that spermatozoa incubated in ampullary oviductal fluid 
collected during the nonluteal stage of the oestrous cycle had more acrosome reactions than those incubated in fluid collected from the isthmus region, without decreasing sperm viability. Collectively, these findings suggest that there are functional differences between the ampullary and isthmic regions of the mammalian oviduct.

Although several studies have investigated the ability of oviductal fluid proteins to bind to the zona pellucida (Boice et al., 1990; Wegner and Killian, 1991; Malette and Bleau, 1993; Boatman et al., 1994; Reuter et al., 1994; Staros and Killian, 1995) or to the early embryo (Gandolfi et al., 1989; Boice et al., 1990; Wegner and Killian, 1991; Boice et al., 1992; Kan et al., 1993), the effects of oviductal fluid on the binding of spermatozoa to the zona pellucida and subsequent penetration of the ova following incubation of both gametes in oviductal fluid have not been described. Moreover, it is not known how oviductal fluid from different oviductal regions may affect sperm-egg binding and fertilization. This study was undertaken to define more clearly the role of fluid from different regions of the oviduct on sperm-egg interaction at fertilization.

\section{Materials and Methods}

\section{Oviductal fluid collection and preparation}

Whole oviductal fluid was collected daily from Holstein cows (Bos taurus) with indwelling oviductal cannulae (Kavanaugh and Killian, 1988). Daily samples were combined into nonluteal and luteal whole oviductal fluid pools based on daily serum progesterone concentrations. Nonluteal (serum progesterone $\leq 1.5 \mathrm{ng} \mathrm{ml}^{-1}$ ) and luteal (serum progesterone $>1.5 \mathrm{ng} \mathrm{ml}^{-1}$ ) whole oviductal fluid samples from three cows were combined into luteal and nonluteal pools. Pools of whole oviductal fluid were filtered $(0.45 \mu \mathrm{m})$, and stored at $-70^{\circ} \mathrm{C}$ until use.

Fluids from the isthmic and ampullary regions of the oviduct were collected from indwelling regional cannulae as described by Kavanaugh et al. (1992). Regional oviductal fluid was combined for luteal and nonluteal stages of the oestrous cycle based on daily serum progesterone concentrations as described for whole oviductal fluid. Fluids from three cows were pooled, filtered as described above, and stored at $-70^{\circ} \mathrm{C}$ until use.

\section{Sperm preparation and capacitation}

Semen was collected from three mature, Holstein dairy bulls by artificial vagina. Ejaculates were pooled ( $1 \mathrm{ml}$ from each bull), washed in modified Tyrode's Medium (MTM, Parrish et al., 1988) and centrifuged at $500 \mathrm{~g}$ for $10 \mathrm{~min}$. The supernatant was removed and spermatozoa were resuspended in MTM and centrifuged again. Spermatozoa $\left(5 \times 10^{7}\right)$ were incubated in $1 \mathrm{ml}$ MTM supplemented with heparin $(10 \mu \mathrm{g}$ $\mathrm{ml}^{-1}$ ) for $4 \mathrm{~h}$ to capacitate the spermatozoa and served as the positive control for all experiments (McNutt and Killian, 1991). In addition, for experiments involving incubation of spermatozoa in oviductal fluid, $5 \times 10^{7}$ spermatozoa ml ${ }^{-1}$ were incubated in $60 \%$ oviductal fluid $/ 40 \%$ MTM $(\mathrm{v} / \mathrm{v})$ for $4 \mathrm{~h}$ before insemination.

\section{Oocyte collection and in vitro fertilization}

Bovine ovaries obtained from a local abattoir were transported at $39^{\circ} \mathrm{C}$, washed, and aspirated as described by $\mathrm{McNutt}$ and Killian (1991). Cumulus-oocyte complexes and follicular fluid aspirated from follicles $1-6 \mathrm{~mm}$ in diameter were combined in $15 \mathrm{ml}$ conical tubes and kept at $39^{\circ} \mathrm{C}$ for $30 \mathrm{~min}$ to allow the cumulus-oocyte complexes to settle to the bottom of the tube. Sediment from each tube was washed in low bicarbonate-Hepes medium (Bavister et al., 1983) and oocytes were recovered.

The COC were matured in groups of ten in $50 \mu$ drops of maturation medium under heavy mineral oil (McNutt and Killian, 1991) for $22-24 \mathrm{~h}$ at $39^{\circ} \mathrm{C}, 5 \% \mathrm{CO}_{2}$ in air. Mature oocytes with expanded cumulus cell masses were then placed in a $0.5 \mathrm{ml}$ microcentrifuge tube with approximately $250 \mu \mathrm{l}$ low bicarbonate-Hepes medium and vortexed for $3 \mathrm{~min}$ to remove cumulus cells. Oocytes were washed once in fertilization medium (Bavister et al., 1983), and placed in groups of ten in $50 \mu \mathrm{l}$ drops containing $60 \%$ oviductal fluid and $40 \%(\mathrm{v} / \mathrm{v})$ fertilization medium under heavy mineral oil for $2 \mathrm{~h}$. Oocytes in fertilization medium alone served as the positive control. After incubation in oviductal fluid or fertilization medium, oocytes were washed once in fertilization medium and placed in fresh $50 \mu \mathrm{l}$ drops of fertilization medium under heavy mineral oil.

Oocytes were coincubated with $1 \times 10^{5}$ spermatozoa per fertilization drop. After $18-20 \mathrm{~h}\left(39^{\circ} \mathrm{C}, 5 \% \mathrm{CO}_{2}\right.$ in air), oocytes were removed from co-culture, washed in low bicarbonateHepes medium, and placed on slides. Half of the oocytes from each treatment were fixed in acid alcohol and stained with $1 \%$ aceto-orcein (Sirard et al., 1988) to assess fertilization. The remainder of the oocytes were evaluated for sperm binding.

\section{Determination of sperm binding}

Oocytes were placed, ten per slide, under a coverslip mounted with paraffin wax and petroleum jelly at each corner. The coverslip was gently lowered over the oocytes until they burst, and the cytoplasm was rinsed away leaving the zonae pellucidae behind. The zona pellucida and spermatozoa attached to it were stained with Hoechst fluorescent dye (33342, Sigma, St Louis, MO) to determine the number of spermatozoa bound to each zona pellucida using fluorescence microscopy (Way et al., 1994) (Fig. 1).

\section{Incubation of oocytes in whole and regional oviductal fluid}

In vitro matured, cumulus-free oocytes were incubated for $2 \mathrm{~h}$ in $60 \%$ whole or regional oviductal fluid from either the luteal or nonluteal stages of the oestrous cycle and $40 \%(\mathrm{v} / \mathrm{v})$ fertilization medium to determine whether sperm binding to the zona pellucida and fertilization rates were different if oocytes were incubated in ampullary versus isthmic oviductal fluid. The treatments were: oocytes in whole luteal or nonluteal oviductal fluid, oocytes incubated in ampullary, isthmic nonluteal or luteal oviductal fluid. Oocytes were washed as described earlier and inseminated with $1 \times 10^{5}$ heparincapacitated spermatozoa per microdrop. After coincubation, oocytes were assessed for both sperm binding and fertilization. 


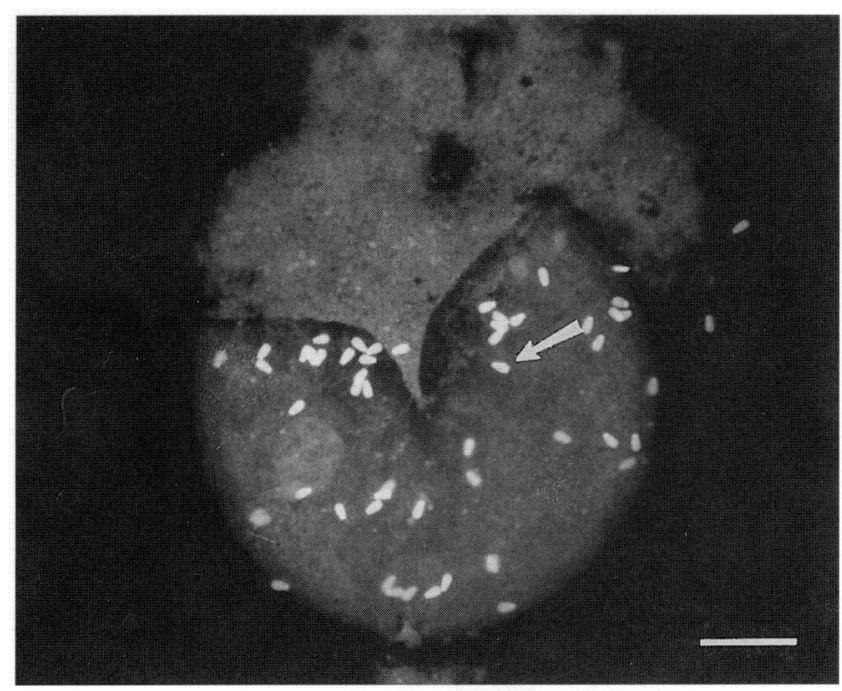

Fig. 1. Bovine spermatozoa attached to a zona pellucida. Each zona was stained with Hoechst 33342 fluorescent dye and the number of spermatozoa (arrow) bound to each zona was counted. Scale bar represents $50 \mu \mathrm{m}$.

Incubation of spermatozoa and oocytes in nonluteal oviductal fluid

Both spermatozoa and oocytes were incubated in either whole or regional nonluteal oviductal fluid to assess the effects of regional oviductal fluid on sperm-zona binding and fertilization if both gametes were incubated in the same or contrasting oviductal fluid. Oocytes were incubated in oviductal fluid for $2 \mathrm{~h}$ and washed as described above. Before insemination, ejaculated bull spermatozoa were washed twice in MTM and then incubated in $60 \%$ whole, ampullary, or isthmic nonluteal oviductal fluid with $40 \%$ (v/v) MTM for 4 h. Positive control spermatozoa were incubated in heparin.

After incubation with oviductal fluid or heparin, $1 \times 10^{5}$ spermatozoa were placed in each microdrop of fertilization medium containing ten oocytes. The treatments in this experiment were: both spermatozoa and oocytes incubated in ampullary oviductal fluid; both spermatozoa and oocytes incubated in isthmic oviductal fluid; spermatozoa incubated in isthmic oviductal fluid and oocytes incubated in ampullary oviductal fluid; both spermatozoa and oocytes incubated in whole oviductal fluid. Heparin-capacitated spermatozoa and oocytes in fertilization medium alone were used as a positive control. Gametes were coincubated for $18-20 \mathrm{~h}$ and then analysed for sperm binding and penetration.

\section{Effects of regional oviductal fluid on time of fertilization}

The effects of oviductal fluid on the interval of time until fertilization were determined by conducting another series of experiments in which oocytes and spermatozoa were incubated in oviductal fluid as outlined in the previous experiment and were then coincubated for 14,16 or $18 \mathrm{~h}$. The methods for this experiment were identical to those described for oocytes and spermatozoa incubated in oviductal fluid, but sperm binding was not analysed. At the end of each coincubation experiment, oocytes were washed, fixed in acid alcohol, and stained with $1 \%$ aceto-orcein to assess fertilization.

\section{Statistical analysis}

Experiments were repeated twice, and the data were pooled if day to day variability was not significant. Microdrops (five per treatment) served as replicates for both sperm binding and penetration. Analysis of variance (SAS Institute Incorporated, 1985) was performed using mean number of spermatozoa bound per zona pellucida for each treatment in binding experiments and using a weighted mean based on number of oocytes per treatment in fertilization experiments. Least square means and Bonferroni means comparisons were used to assess sperm binding. Weighted least square means were used to analyse fertilization data. The significance level for all tests was $P<0.05$.

\section{Results}

\section{Incubation of oocytes in whole and regional oviductal fluid}

More heparin-capacitated spermatozoa bound to oocytes incubated in nonluteal than in luteal whole oviductal fluid $(P<0.05$, Fig. 2a). However, for fertilization, differences between nonluteal and luteal oviductal fluid were not significant (Fig. 2b). More spermatozoa bound to oocytes incubated with isthmic oviductal fluid than those incubated in ampullary oviductal fluid $(P<0.01$, Fig. 3a). Within the nonluteal stage of the oestrous cycle, more spermatozoa bound to the zonae pellucidae of oocytes incubated in isthmic than in ampullary oviductal fluid $(P=0.0001)$. More spermatozoa penetrated oocytes incubated in isthmic nonluteal than luteal oviductal fluid $(P<0.05$, Fig. 3b); there were no other significant differences regarding fertilization.

\section{Incubation of spermatozoa and oocytes in nonluteal oviductal fluid}

In preliminary studies we further considered sperm binding and penetration when both gametes were incubated in nonluteal and luteal oviductal fluid. Because binding and fertilization were only improved when oocytes were incubated in nonluteal oviductal fluid, successive experiments focused on nonluteal oviductal fluid.

More spermatozoa bound to oocytes when both gametes were incubated in ampullary oviductal fluid, than when both were incubated in isthmic oviductal fluid or whole oviductal fluid, or in control medium $(P=0.0001$, Table 1). More spermatozoa bound to oocytes if both gametes were incubated in the same oviductal fluid, rather than if spermatozoa were incubated in isthmic and eggs in ampullary oviductal fluid $(P<0.05)$. Although at $18-20 \mathrm{~h}$ the percentage of oocytes showing evidence of fertilization was similar (data not shown), some treatments appeared to have fertilized oocytes at more advanced stages of development than others. This led us to test whether the type of oviductal fluid had an effect on the interval when first evidence of fertilization was observed.

In vitro fertilization of gametes preincubated in oviductal fluid, time of coincubation titration

At both 14 and $16 \mathrm{~h}$ of coincubation, more oocytes were fertilized when spermatozoa were incubated in isthmic 


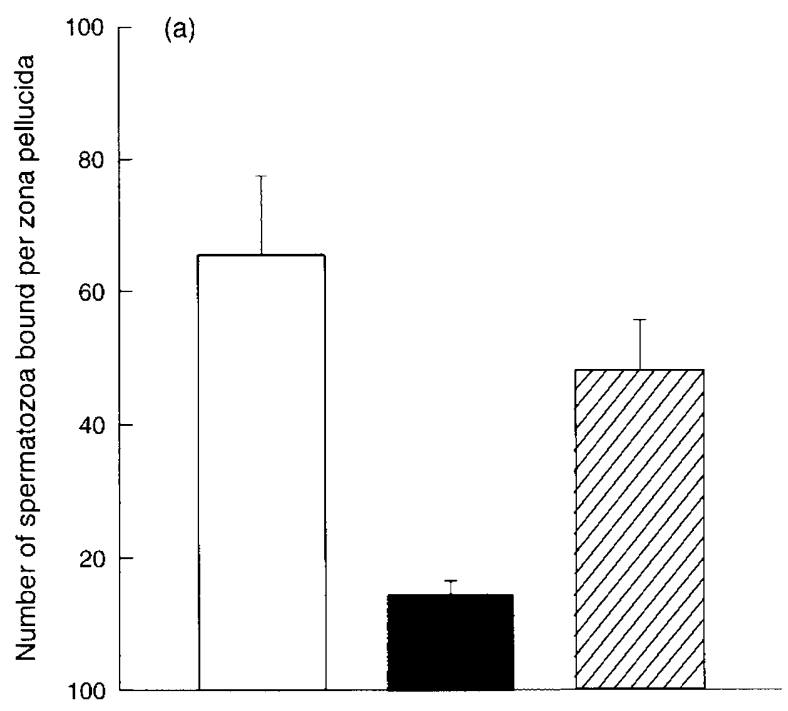

(b)

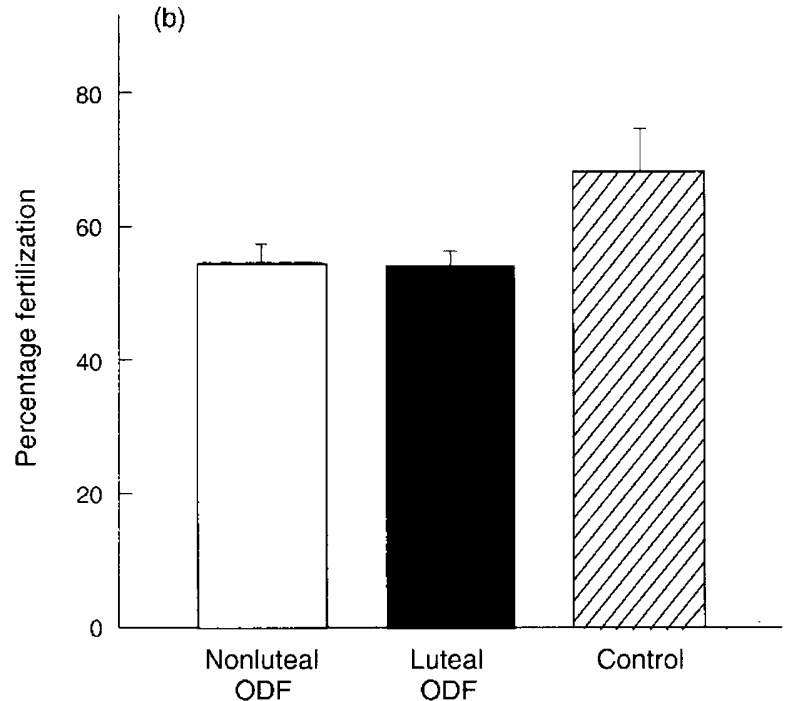

Fig. 2. Incubation of bovine oocytes in whole oviductal fluid (ODF). Mean ( \pm SEM) (a) number of spermatozoa bound per zona pellucida and (b) percentage fertilization when oocytes were preincubated in nonluteal $(\square)$ or luteal ( $\square$ ) oviductal fluid or control $(\square)$ before insemination.

oviductal fluid and oocytes were incubated in ampullary oviductal fluid, than when oocytes and spermatozoa were incubated in ampullary or whole oviductal fluid, or in the control $(P<0.05$, Table 2). Also, at 14 and $16 \mathrm{~h}$, more oocytes were fertilized when both gametes were incubated in isthmic oviductal fluid than when incubated in whole oviductal fluid or the control $(P<0.05)$. By $18 \mathrm{~h}$ of coincubation, there were few differences between treatments. Fertilization increased over time in each treatment, but this increase was only significant in gametes incubated in whole oviductal fluid and in the control $(P<0.05)$.

\section{Discussion}

More spermatozoa bound to zonae pellucidae of oocytes incubated in nonluteal oviductal fluid than those incubated in
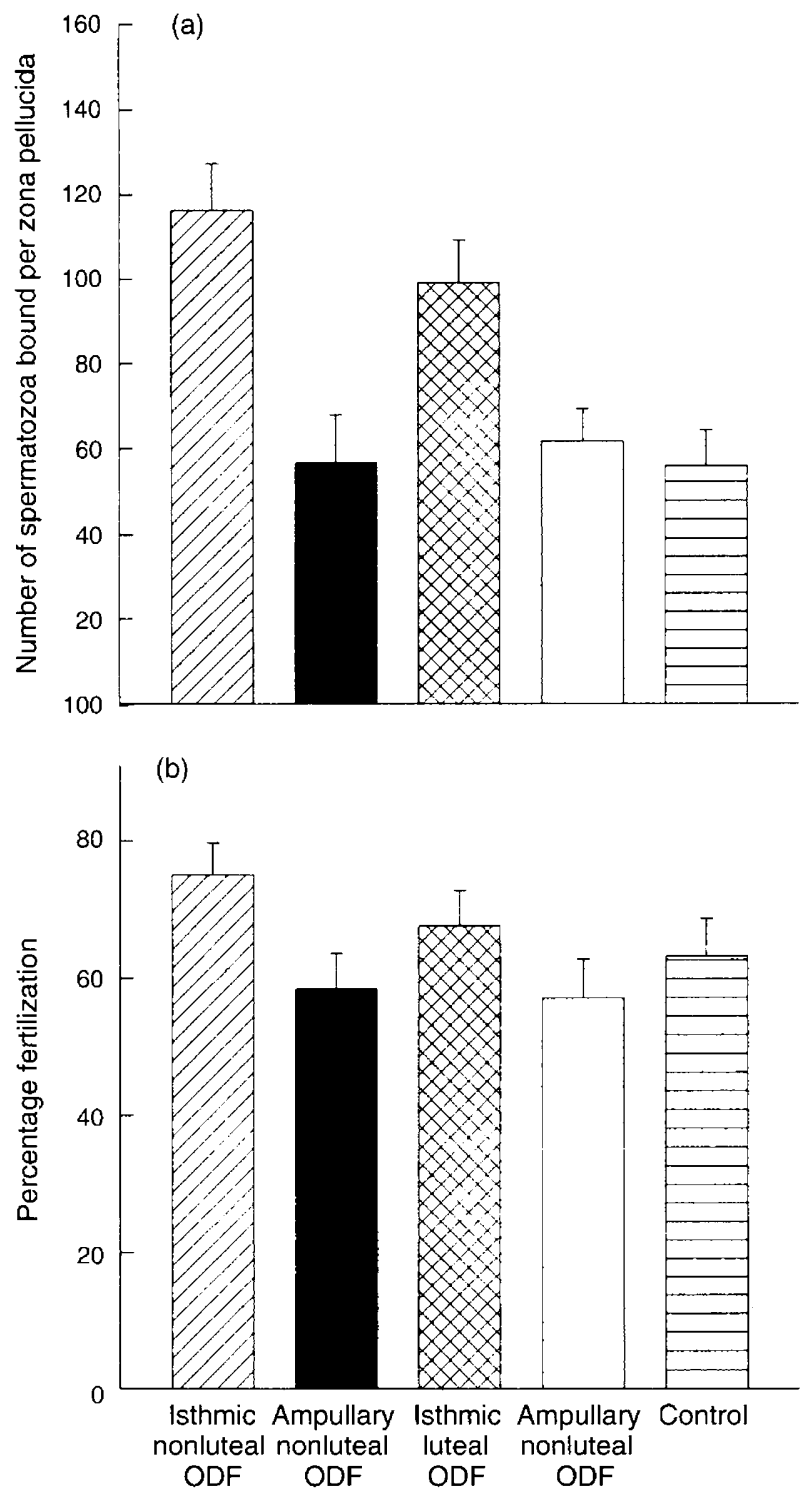

Fig. 3. Incubation of bovine oocytes in regional oviductal fluid (ODF). Mean ( \pm SEM) (a) number of spermatozoa bound per zona pellucida and (b) percentage fertilization when oocytes were preincubated in luteal or nonluteal regional oviductal fluid before insemination: isthmic

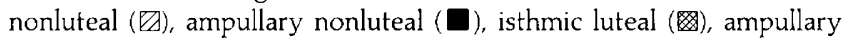
luteal ( $\square$ ) oviductal fluid, or the control (目).

luteal oviductal fluid, indicating that the stage of the oestrous cycle during which oviductal fluid was obtained influences sperm binding. Regardless of the stage of the oestrous cycle, more spermatozoa bound to zonae incubated in isthmic than ampullary oviductal fluid, suggesting a functional difference between secretions of the isthmic and ampullary regions of the oviduct. Within the isthmus, more spermatozoa bound to zonae incubated in nonluteal than luteal oviductal fluid, again indicating an interaction between stages of the oestrous cycle and region of the oviduct. Overall, sperm binding was enhanced if both gametes were incubated in ampullary oviductal fluid.

Because both fertilization and binding were significantly lower when gametes were incubated in whole oviductal fluid 
Table 1. Number of bovine spermatozoa per zona pellucida when both gametes were incubated in nonluteal oviductal fluid $(\mathrm{ODF})^{*}$

\begin{tabular}{ccccc}
\hline & Both gametes in: & WODF & $\begin{array}{c}\text { Spermatozoa in } \\
\text { IODF; oocytes } \\
\text { in AODF }\end{array}$ & $\begin{array}{c}\text { Spermatozoa in } \\
\text { heparin; oocytes in } \\
\text { medium }\end{array}$ \\
\hline AODF & IODF & WOD & $32.80 \pm 2.77^{\mathrm{d}}$ \\
\hline
\end{tabular}

* Results are expressed as means \pm SEM of spermatozoa bound per zona when both gametes were preincubated in ampullary (AODF), isthmic (IODF) or whole (WODF) ODF before insemination.

a.b.c.dValues with different superscripts within rows are significantly different $(P<0.05)$.

Table 2. Percentage fertilized bovine oocytes after incubation of both spermatozoa and oocytes in nonluteal oviductal fluid $(\mathrm{ODF})^{*}$

\begin{tabular}{lccccc}
\hline \multirow{3}{*}{$\begin{array}{c}\text { Time } \\
\text { (h) }\end{array}$} & Both gametes in: & & $\begin{array}{c}\text { Spermatozoa in } \\
\text { IODF; oocytes } \\
\text { in AODF }\end{array}$ & $\begin{array}{c}\text { Spermatozoa in } \\
\text { heparin; oocytes in } \\
\text { medium }\end{array}$ \\
\cline { 2 - 5 } & AODF & IODF & WODF & & \\
\hline 14 & $61.83 \pm 9.72^{\mathrm{a}}$ & $64.44 \pm 6.95^{\mathrm{ab}}$ & $46.97 \pm 7.81^{\mathrm{c}}$ & $76.00 \pm 8.36^{\mathrm{b}}$ & $49.43 \pm 10.01^{\mathrm{c}}$ \\
16 & $66.11 \pm 13.28^{\mathrm{a}}$ & $72.34 \pm 8.34^{\mathrm{ab}}$ & $56.90 \pm 6.77^{\mathrm{c}}$ & $74.89 \pm 4.55^{\mathrm{b}}$ & $51.04 \pm 9.06^{\mathrm{c}}$ \\
18 & $61.81 \pm 5.60^{\mathrm{a}}$ & $72.54 \pm 7.02^{\mathrm{ab}}$ & $82.22 \pm 9.20^{\mathrm{b}}$ & $84.72 \pm 9.72^{\mathrm{b}}$ & $77.54 \pm 3.99^{\mathrm{b}}$ \\
\hline
\end{tabular}

*Results are expressed as means \pm SF: of oocytes fertilized by spermatozoa when both gametes were preincubated in nonluteal ampullary (AODF), isthmic (IODF) or whole (WODF) ODF before insemination. 96-104 oocytes per treatment.

${ }^{a, b, c}$ Values with different superscripts within rows are significantly different $(P<0.05)$.

than in isthmic oviductal fluid, there appear to be significant functional differences associated with ampullary and isthmic oviductal fluid. Optimal results were observed in vitro with regional oviductal fluid that paralleled the situation in vivo where oocytes are first exposed to ampullary then isthmic oviductal fluid, and spermatozoa are exposed to isthmic then ampullary oviductal fluid. Because fertilization is thought to occur at the ampullary-isthmic junction and the movement of oviductal fluid at ovulation is thought to be towards the infundibulum (Perkins, 1974), the number of spermatozoa exposed to ampullary oviductal fluid at fertilization is probably limited. Although some mixing of ampullary and isthmic oviductal fluid may occur at the junction between these two regions, spermatozoa exposed to oviductal fluid in the ampulla have probably passed the site of fertilization and are destined to die without coming into contact with an egg.

By decreasing sperm concentrations in vitro to physiological values (hundreds instead of hundreds of thousands) it may be possible to detect more subtle differences in the effect of nonluteal oviductal fluid obtained from the different regions of the oviduct on fertilization. Although not statistically significant, the treatment in which spermatozoa were incubated in isthmic oviductal fluid and oocytes were incubated in ampullary oviductal fluid before fertilization tended to have a higher percentage of fertilization than when both gametes were incubated in isthmic oviductal fluid. It is not surprising that spermatozoa exposed to isthmic and eggs exposed to ampullary nonluteal oviductal fluid would show maximal fertilization, because this is the natural sequence of exposure before fertilization in vivo. Spermatozoa may be modified in the isthmus before they arrive at the site of fertilization by acquiring a factor(s) that facilitates binding or penetration.

It also is possible that a pre-existing sperm factor is modified by isthmic oviductal fluid. Several studies examining the effect of oviductin on sperm capacitation and the acrosome reaction have shown that this glycoprotein, synthesized and secreted by the hamster oviduct, binds to spermatozoa both before and after capacitation, and that it enhances penetration of spermatozoa through the zona pellucida (Boatman et al., 1994; Boatman and Magnoni, 1995).

Hamster oviductin shares homology with bovine, baboon, and human oviductal glycoproteins (Arias et al., 1994; Suzuki et al., 1995). In cows, although ampullary oviductal explants harvested at the time of oestrus produced significantly more of a $95 \mathrm{kDa}$ oestrus-associated protein (EAP) than did oestrus isthmic explants (Wegner and Killian, 1992), oocytes incubated in isthmic nonluteal oviductal fluid had greater immunofluorescence when reacted with EAP antiserum, than did oocytes incubated in ampullary nonluteal oviductal fluid (Wegner and Killian, 1991). They speculated that EAP may modify zona pellucida proteins that serve as sperm receptors or inducers of the acrosome reaction. Subsequently, bovine EAP has been shown to stimulate sperm capacitation and fertilization (King et al., 1994).

Glycosaminoglycans (GAG) also promote the fertilizing ability of spermatozoa (Handrow et al., 1982; Lenz et al., 1983). Although Grippo et al. (1995) did not detect differences in total GAG content of regional, staged oviductal fluid, they did not differentiate between free and proteinbound GAGs. Anderson and Killian (1994) found that medium conditioned by oestrous isthmic explants had 
significantly more protein-associated GAG than did conditioned medium of oestrous ampullary explants. In addition, oestrous isthmic conditioned medium capacitated more spermatozoa than did oestrous ampullary conditioned medium at $4 \mathrm{~h}$ of incubation. One capacitating factor available to spermatozoa in the isthmus may be a GAG covalently bound to a protein, which may facilitate sperm binding to the zona pellucida and the acrosome reaction.

The number of spermatozoa bound per zona pellucida was much higher in the present study than the number of spermatozoa that actually reach the site of fertilization in vivo (Harper, 1982). Moreover, to observe maximal differences in fertilization rates between oviductal fluid from different regions of the oviduct, coincubations of $16 \mathrm{~h}$ or less were ideal. By $14 \mathrm{~h}$ significant differences in the function of oviductal fluid from different regions of the oviduct were seen. This, in conjunction with a lower sperm concentration, might reveal even more subtle differences in oviductal fluid from different regions of the oviduct and stages of the oestrous cycle.

Despite the fact that sperm concentrations in the current experiments were not physiological, it is clear that sperm binding and fertilization were affected differently by isthmic and ampullary oviductal fluids. This study adds to the growing body of evidence suggesting that oviductal fluid factors influence sperm binding, fertilization, and early embryonic development. Specifically, oviductal fluid may prepare a population of capacitated spermatozoa primed for fertilization, as well as facilitate timely fertilization and development of the newly emerging embryo.

The assistance of the staff at the Dairy Breeding Research Center is greatly appreciated. This work was supported in part by USDA grant 91-37203-6554

\section{References}

Abe H, Sendai Y, Satoh T and Hoshi H (1995) Bovine oviduct-specific glycoprotein: a potent factor for maintenance of viability and motility of bovine spermatozoa in vitro. Molecular Reproduction and Development 42 226-232

Anderson SH and Killian GJ (1994) Effect of macromolecules from oviductal conditioned medium on bovine sperm motion and capacitation Biology of Reproduction 51 795-799

Arias EB, Verhage HG and Jaffe RC (1994) Complementary deoxyribonucleic acid cloning and molecular characterization of an estrogen-dependent human oviductal glycoprotein Biology of Reproduction 51 685-694

Bavister BD, Leibfried ML and Lieberman G (1983) Development of preimplantation embryos of the golden hamster in defined medium Biology of Reproduction 28 235-247

Boatman DE and Magnoni GE (1995) Identification of a sperm penetration factor in the oviduct of the golden hamster Biology of Reproduction 52 199-207

Boatman DE, Felson SE and Kimura J (1994) Changes in morphology, sperm penetration and fertilization of ovulated hamster eggs induced by oviductal exposure Human Reproduction 9 519-526

Boice ML, McCarthy TJ, Mavrogianis PA, Fazleabas AT and Verhage HG (1990) Localization of oviductal glycoproteins within the zona pellucida and perivitelline space of ovulated ova and early embryos in baboons (Papio anubis) Biology of Reproduction 43 340-346

Boice ML, Mavrogianis PA, Murphy CN, Prather RS and Day BN (1992) Immunocytochemical analysis of the association of bovine oviduct-specific glycoproteins with early embryos Journal of Experimental Zoology 263 $225-229$
Buhi WC, Vallet JL and Bazer FW (1989) De novo synthesis and release of polypeptides from cyclic and early pregnant porcine oviductal tissue in explant culture Joumal of Experimental Zoology 252 79-88

Buhi WC, Alvarez IM, Sudhipong V and Dones-Smith MM (1990) Identification and characterization of de novo-synthesized porcine oviductal secretory proteins Biology of Reproduction 43 929-938

Carlson D, Black DL and Howe GR (1970) Oviduct secretion in the cow Journal of Reproduction and Fertility 22 549-552

Ehrenwald E, Foote RH and Parks JE (1990) Bovine oviductal fluid components and their potential role in sperm cholesterol efflux Molecular Reproduction and Development 25 195-204

Gandolfi F, Brevini TAL, Richardson L, Brown CR and Moor RM (1989) Characterization of proteins secreted by sheep oviduct epithelial cells and their function in embryonic development Development 106 303-312

Gerena RL and Killian GJ (1990) Electrophoretic characterization of proteins in oviduct fluid of cows during the estrous cycle Journal of Experimental Zoology 256 113-120

Grippo AA, Henault MA, Anderson SH and Killian GJ (1992) Cation concentrations in fluid from the oviduct ampulla and isthmus of cows during the estrous cycle Journal of Dairy Science 75 58-65

Grippo AA, Way AL and Killian GJ (1995) Effect of bovine ampullary and isthmic oviductal fliud on motility, acrosome reaction and fertility of bull spermatozoa Journal of Reproduction and Fertility 105 57-64

Handrow RR, Lenz RW and Ax RL (1982) Structural comparisons among glycosaminoglycans to promote an acrosome reaction in bovine spermatozoa Biochemical Biophysical Research Communications 107 1326-1332

Harper MJK (1982) Sperm and egg transport. In Reproduction in Mammals. I. Germ Cells and Fertilization, Edn 2 pp 102-127 Eds. CR Austin and RV Short. Cambridge University Press, Cambridge.

Hyde BA and Black DL (1986) Synthesis and secretion of sulphated glycoproteins by rabbit oviduct explants in vitro. Journal of Reproduction and Fertility 78 83-91

Kan FW, Roux E and Bleau G (1993) Immunolocalization of oviductin in endocytic compartments in the blastomeres of developing embryos in the golden hamster Biology of Reproduction 48 77-88

Kavanaugh JF and Killian G) (1988) Bovine oviductal cannulations Journal of Investigative Surgery 1 20I-208

Kavanaugh JF, Grippo AA and Killian GJ (1992) Cannulation of the bovine ampullary and isthmic oviduct journal of Investigative Surgery 5 11-17

Killian GJ, Chapman DA, Kavanaugh JF, Deaver DR and Wiggin HB (1989) Changes in phospholipids, cholesterol and protein content of oviduct fluid of cows during the oestrous cycle Journal of Reproduction and Fertility 86 $419-426$

Kimura H, Matsuda J, Ogura A, Asano T and Naiki M (1994) Affinity binding of hamster oviductin to spermatozoa and its influence on in vitro fertilization Molecular Reproduction and Development $39322-327$

King RS and Killian GJ (1994) Purification of bovine estrus-associated protein and localization of binding on sperm Biology of Reproduction 51 34-42

King RS, Anderson SH and Killian GJ (1994) Effect of bovine oviductal estrus-associated protein on the ability of sperm to capacitate and fertilize oocytes Journal of Andrology 15 468-478

Lenz RW, Ball GD, Lohse JK, First NL and Ax RL (1983) Chondroitin sulphate facilitates an acrosome reaction in bovine spermatozoa as evidenced by light microscopy, electron microscopy, and in vitro fertilization Biology of Reproduction 28 683-690

McNutt TL and Killian GJ (1991) Influence of bovine follicular and oviduct fluids on sperm capacitation in vitro. Journal of Andrology 12 244-252

McNutt TL, Rogowski L, Vasilatos-Younken R and Killian G (1992) Adsorption of oviductal fluid proteins by the bovine sperm membrane during in vitro capacitation Molecular Reproduction and Development 53 313-323

McNutt TL, Olds-Clarke P, Way AL, Suarez SS and Killian GJ (1994) Effect of follicular or oviductal fluids on movement characteristics of bovine sperm during capacitation in vitro. Journal of Andrology 15 328-336

Malette B and Bleau G (1993) Biochemical characterization of hamster oviductin as a sulphated zona pellucida-binding glycoprotein Biochemical journal 295 $437-445$

Parrish JJ, Susko-Parrish JL, Winer MA and First NL (1988) Capacitation of bovine sperm by heparin Biology of Reproduction 38 1171-1180

Parrish JJ, Susko-Parrish JL, Handrow RR, Sims MM and First NL (1989) Capacitation of bovine spermatozoa by oviduct fluid Biology of Reproduction 40 1020-1025 
Perkins JL (1974) Fluid flow of the oviduct. In The Oviduct and its Functions pp 119-129 Eds. AD Johnson and CW Foley. Academic Press, Inc., New York

Reuter LM, O'Day-Bowman MB, Maviogianis PA, Fazleabas AT and Verhage HG (1994) In vitro incubation of golden (Syrian) hamster ovarian oocytes and human sperm with a human oviduct specific glycoprotein Molecular Reproduction and Development $9519-526$

Roberts GP, Parker JM and Symonds HW (1975) Proteins in the luminal fluid from the bovine oviduct Journal of Reproduction and Fertility 45 301-313

Rodriguéz CM and Killian GJ (1995) Effect of estrous cycle stage and region of the oviduct on oviduct fluid proteins that associate with the sperm membrane Biology of Reproduction Supplement 152117

SAS Institute Incorporated (1985) SAS User's Guide: Statistics, Version 5 SAS Institute Inc., Gary, North Carolina

Sirard MA, Parrish JJ, Ware CB, Leibfried-Rutledge ML and First NL (1988) The culture of bovine oocytes to obtain developmentally competent embryos Biology of Reproduction 39 546-552
Staros AL and Killian GJ (1995) Six oviductal fluid (ODF) proteins associate with the bovine zona pellucida in vitro. Biology of Reproduction Supplement 1 52117

Suzuki K, Sendai Y, Onuma T, Hoshi H, Hiroi M and Araki Y (1995) Molecular characterization of a hamster oviduct-specific glycoprotein Biology of Reproduction 53 345-354

Verhage HG and Fazleabas AT (1988) The in vitro synthesis of estrogen dependent proteins by the baboon (Papio anubis) oviduct Endocrinology 123 552-558

Way AL, Schuler AM and Killian GJ (1994) Effect of oviduct fluid (ODF) on sperm binding and penetration of bovine oocytes in vitro. Biology of Reproduction Supplement 150300

Wegner CC and Killian GJ (1991) In vitro and in vivo association of an oviduct estrus-associated protein with bovine zona pellucida Molecular Reproduction and Development 29 77-84

Wegner CC and Killian GJ (1992) Origin of oestrus-associated glycoproteins in bovine oviductal fluid journal of Reproduction and Fertility 95 841-854 